\title{
The current distribution pattern of Biomphalaria tenagophila and Biomphalaria straminea in the northern and southern regions of the coastal fluvial plain in the state of São Paulo
}

\author{
Raquel Gardini Sanches Palasio ${ }^{I}$, Marcia Oliveira Casotti ${ }^{1}$, Thamiris Cassia Rodrigues ${ }^{\text {, }}$ \\ Regiane Maria Tirone Menezes ${ }^{2}$, Eliana Maria Zanotti-Magalhaes ${ }^{3}$ \& Roseli Tuan ${ }^{1,4}$ \\ ${ }^{1}$ Superintendencia de Controle de Endemias, Laboratório de Bioquímica e Biologia Molecular \\ São Paulo, SP, Brazil. \\ ${ }^{2}$ Superintendencia de Controle de Endemias, Laboratório de Entomologia, São Paulo, SP, Brazil. \\ ${ }^{3}$ Universidade Estadual de Campinas, Departamento de Biologia Animal, São Paulo, SP, Brazil. \\ ${ }^{4}$ Corresponding author: Roseli Tuan,e-mail: roselituan@gmail.com
}

PALASIO, R.G.S., CASOTTI, M.O., RODRIGUES, T.C., MENEZES, R.M.T., ZANOTTIMAGALHAES, E.M., TUAN, R. The current distribution pattern of Biomphalaria tenagophila and Biomphalaria straminea in the northern and southern regions of the coastal fluvial plain in the state of São Paulo. Biota Neotropica. 15(3): e20140153. http://dx.doi.org/10.1590/1676-06032015015314

\begin{abstract}
We analyze the current distribution of snails from genus Biomphalaria in the north and south of the coastal fluvial plain in the state of São Paulo, which is part of a large coastal floodplain. Data from twenty-nine collection sites confirmed that the freshwater body in both regions is colonized by Biomphalaria tenagophila and Biomphalaria straminea, which are natural intermediate hosts of Schistosoma mansoni. The abundance of B. straminea in collection sites where only B. tenagophila had previously been recorded indicates the potential for $B$. straminea to expand in the region. While quantitative analysis of the number of specimens per species showed that local growth of B. tenagophila populations occurs during periods with little rainfall, there is a greater risk of $B$. tenagophila populations spreading between different water bodies during rainy periods, when heavy rainfall results in water levels rising in the main rivers and flooding caused by water flowing from the Serra do Mar mountain range to the coastal plain. The temperature increase caused by global climate changes and the consequent increasing frequency of high-water levels and floods can be expected to affect the distribution of these snails on the coastal fluvial plain, leading to the risk of a change in the autochthonous transmission pattern of schistosomiasis in the region.
\end{abstract}

Keywords: B. tenagophila, B. straminea, schistosomiasis, climate change

Financial support: CAPES, FAPESP 07/03458-7, SUCEN.

PAlASIO, R.G.S., CASOTTI, M.O., RODRIGUES, T.C., MENEZES, R.M.T., ZANOTTIMAGAlHAES, E.M., TUAN, R. Padrão atual de distribuição de Biomphalaria tenagophila e Biomphalaria straminea nos setores norte e sul da planície fluvial costeira do Estado de São Paulo, Brasil. Biota Neotropica. 15(3): e20140153. http://dx.doi.org/10.1590/1676-06032015015314

\begin{abstract}
Resumo: Neste trabalho analisamos a distribuição atual de caramujos do gênero Biomphalaria nos setores norte e sul da planície fluvial da costa litorânea de São Paulo. A região está inserida numa extensa planície costeira inundável. Os dados de 29 sítios de coletas confirmam que a coleção de água doce em ambos os setores é colonizada por Biomphalaria tenagophila e Biompalaria straminea. Ambas as espécies são hospedeiras intermediárias naturais do Schistosoma mansoni. A abundânciade B. straminea em sítios de coleta em que foram registrados recentemente apenas $B$. tenagophila, indica o potencial de expansão de $B$. straminea na região. A análise quantitativa de espécimes/espécie demonstra que o crescimento local das populações de B. tenagophila ocorre em períodos de baixa pluviosidade. Há maior risco de dispersão das populações de B. tenagophila entre diferentes coleções de água em períodos úmidos, quando a alta pluviosidade promove a cheia dos principais rios e inundações decorrentes do escoamento de água da Serra do Mar para a planície costeira. O aumento da temperatura causada por alterações climáticas globais, e consequentemente o aumento de cheias e inundações, deve interferir na distribuição dos caramujos na planície fluvial do litoral, com risco de alteração na transmissão autóctone da esquistossomose nesta região.
\end{abstract}

Palavras-chave: B. tenagophila, B. straminea, esquistossomose, alteracoes climaticas

Apoio Financeiro: CAPES, FAPESP 07/03458-7, SUCEN. 


\section{Introduction}

This study investigates the distribution of species of the genus Biomphalaria Preston 1910 in the coastal region of the state of São Paulo, which is characterized by rocky coastlines and lower-lying areas consisting of plains cut by small rivers (Souza 2005) and valleys that are prone to flooding (Diegues et al. 2001). The region includes diversity hotspots, such as the Atlantic Forest (Carnaval 2009, Viadana \& Cavalcanti 2006), intermingled with areas where the rural and urban landscape has undergone significant transformation as a result of the continual changes wrought by human activity (Souza \& Souza 2004, Borelli 2008). It is an important and extensive distribution area for Biomphalaria tenagophila (d'Orbigny 1835) in the Neotropical region. This species continually colonizes freshwater bodies on the coastal plain, particularly in the valley of the Ribeira do Iguape river, along the northern coast and in the Santos lowlands (Piza 1972, Teles 1989). According to Vaz (1989), the coastal region is an important ancestral distribution area and dispersal center from which the species disperses to the São Paulo plateau and to valleys associated with the Paraíba do Sul river. In addition to $B$. tenagophila, B. straminea (Dunker 1848) colonizes isolated areas in the southern part of the coastal strip (Teles 2005). Both species are intermediate hosts of Schistosoma mansoni, the parasite responsible for transmitting schistosomiasis in Brazil.

Increasing temperatures, changes in rainfall patterns and extreme environmental perturbations caused by man-made climate changes (Parmesan 2006, Rockstrom et al. 2009, Rosenzweig et al. 2008) can affect the biodiversity of freshwater ecosystems directly (Heino et al. 2009) and have an impact on the distribution and dispersion of countless animal species (Nooten et al. 2014), including intermediate hosts associated with the transmission of schistosomiasis (McCreesh \& Booth 2014). The success of public campaigns to promote the control of vectors and intermediate hosts of schistosomiasis will therefore depend in future on combining a knowledge of the biology of these snails with advance mapping of areas from which there is a potential risk of diseases being transmitted.

In the case of planorbid snails from the genus Biomphalaria, temperature, type of freshwater habitat (DE Kock et al. 2004) and mode of reproduction determine the geographic distribution of the species. As with other Basommatophora (Escobar 2011), Biomphalaria reproduces by a combination of selffertilization and cross-fertilization, increasing its ability to colonize new habitats. B. tenagophila and B. straminea are also resistant to drought and can survive desiccation during periods without any water, when their metabolic activity is reduced to basal levels (Tuan \& Simões 1989, Teles, \& Marques 1989, Barbosa et al. 1985, Barbosa et al. 2014).

Modifications caused by climate change and anthropic activity, together with the colonization potential of $B$. tenagophila and B. straminea, may directly affect transmission of human schistosomiasis (Silva 1985, Borelli 2008). In the epidemiologic context, the results of the present study highlight the fundamental importance of malacological and

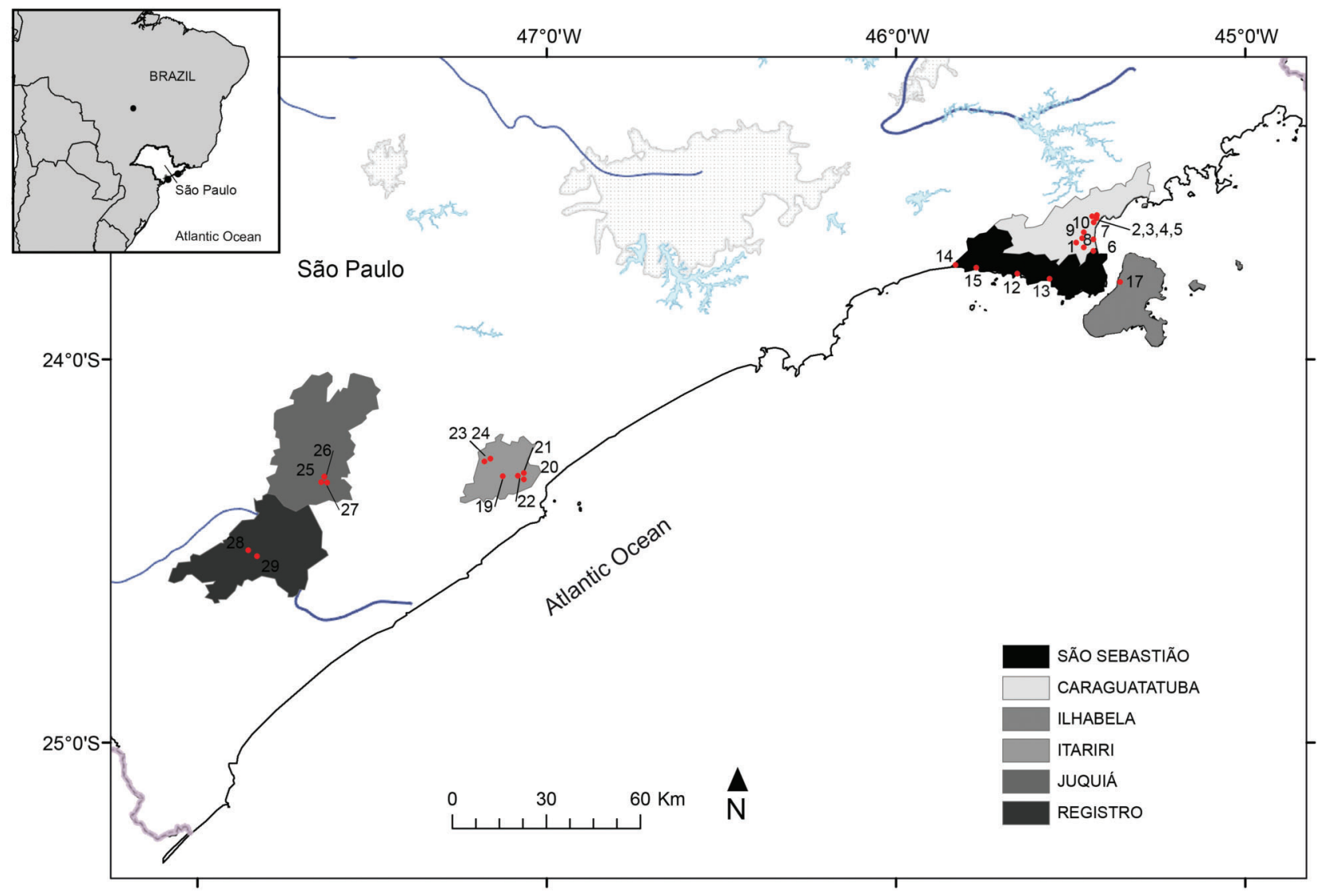

Figure 1. Map of the collection points $(\bullet)$ (North Coast and South Coast/Ribeira do Iguape River) showing the municipalities, (-) rivers/tributaries. (1-10 Caraguatatuba, 11-15 São Sebastião, 16-17 Ilhabela, 18 Ubatuba, 19-24 Itariri, 25-27 Juquiá, 28-29 Registro). 


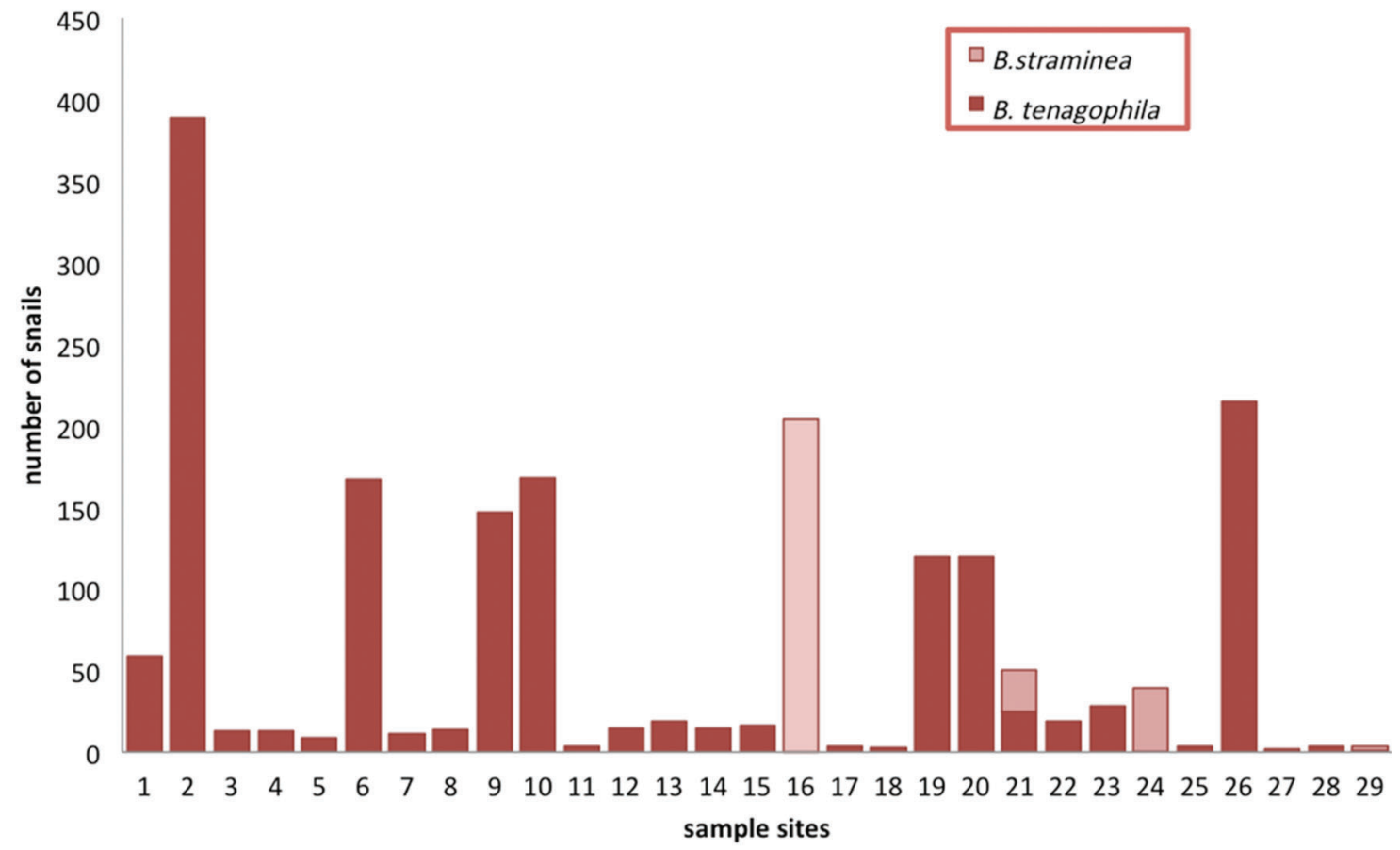

Figure 2. Number of specimens of B. tenagophila and B. straminea collected at the 29 collection points in the drainage basin on the north and south coast of São Paulo. (1-10 Caraguatatuba, 11-15 São Sebastião, 16-17 Ilhabela, 18 Ubatuba, 19-24 Itariri, 25-27 Juquiá, 28-29 Registro).

Table 1. Geographic details of the areas where the snails were collected in the state of São Paulo.

\begin{tabular}{|c|c|c|c|c|}
\hline \multirow{2}{*}{$\frac{\text { Municipality }}{\text { Caraguatatuba }}$} & \multirow{2}{*}{$\frac{\text { Ref. No. }}{1}$} & \multirow{2}{*}{$\frac{\text { Neighborhood }}{\text { Rio Claro }}$} & \multicolumn{2}{|c|}{ Coordinates (Lat. S, Long. W) } \\
\hline & & & $23^{\circ} 41^{\prime} 46^{\prime \prime}$ & $45^{\circ} 28^{\prime} 57^{\prime \prime}$ \\
\hline & $2-5$ & Indaiá-1,2,3,4 & $23^{\circ} 38^{\prime} 42^{\prime \prime}$ & $45^{\circ} 25^{\prime} 14^{\prime \prime}$ \\
\hline & & & $23^{\circ} 37^{\prime} 59^{\prime \prime}$ & $45^{\circ} 25^{\prime} 11^{\prime \prime}$ \\
\hline & & & $23^{\circ} 38^{\prime} 25^{\prime \prime}$ & $45^{\circ} 25^{\prime} 14^{\prime \prime}$ \\
\hline & & & $23^{\circ} 37^{\prime} 55^{\prime \prime}$ & $45^{\circ} 25^{\prime} 08^{\prime \prime}$ \\
\hline & 6 & Travessão & $23^{\circ} 41^{\prime} 49^{\prime \prime}$ & $45^{\circ} 26^{\prime} 30^{\prime \prime}$ \\
\hline & $7-8$ & Porto Novo-1,2 & $23^{\circ} 41^{\prime} 24^{\prime \prime}$ & $45^{\circ} 26^{\prime} 41^{\prime \prime}$ \\
\hline & & & $23^{\circ} 41^{\prime} 34^{\prime \prime}$ & $45^{\circ} 26^{\prime} 58^{\prime \prime}$ \\
\hline & $9-10$ & Morro do Algodão-1,2 & $23^{\circ} 40^{\prime} 42^{\prime \prime}$ & $45^{\circ} 27^{\prime} 18^{\prime \prime}$ \\
\hline & & & $23^{\circ} 40^{\prime} 26^{\prime \prime}$ & $45^{\circ} 26^{\prime} 54^{\prime \prime}$ \\
\hline \multirow[t]{5}{*}{ São Sebastião } & 11 & Canto do Mar & $23^{\circ} 42^{\prime} 58^{\prime \prime}$ & $45^{\circ} 25^{\prime} 53^{\prime \prime}$ \\
\hline & 12 & Camburi & $23^{\circ} 46^{\prime} 20^{\prime \prime}$ & $45^{\circ} 38^{\prime} 50^{\prime \prime}$ \\
\hline & 13 & Maresias & $23^{\circ} 47^{\prime} 15^{\prime \prime}$ & $45^{\circ} 33^{\prime} 24^{\prime \prime}$ \\
\hline & 14 & Boracéia & $23^{\circ} 45^{\prime} 12^{\prime \prime}$ & $45^{\circ} 49^{\prime} 31^{\prime \prime}$ \\
\hline & 15 & Barra do Una & $23^{\circ} 45^{\prime} 25^{\prime \prime}$ & $45^{\circ} 46^{\prime} 07^{\prime \prime}$ \\
\hline \multirow[t]{2}{*}{ Ilhabela } & 16 & Barra Velha & $23^{\circ} 49^{\prime} 17^{\prime \prime}$ & $45^{\circ} 22^{\prime} 01^{\prime \prime}$ \\
\hline & 17 & Itaquanduba & $23^{\circ} 47^{\prime} 56^{\prime \prime}$ & $45^{\circ} 21^{\prime} 44^{\prime \prime}$ \\
\hline Ubatuba & 18 & Sesmaria & $23^{\circ} 27^{\prime} 22^{\prime \prime}$ & $45^{\circ} 05^{\prime} 06^{\prime \prime}$ \\
\hline \multirow[t]{6}{*}{ Itariri } & 19 & Palmito & $24^{\circ} 18^{\prime} 39^{\prime \prime}$ & $47^{\circ} 07^{\prime} 31^{\prime \prime}$ \\
\hline & 20 & Alumínio & $24^{\circ} 18^{\prime} 26^{\prime \prime}$ & $47^{\circ} 03^{\prime} 58^{\prime \prime}$ \\
\hline & 21 & Clay & $24^{\circ} 18^{\prime} 11^{\prime \prime}$ & $47^{\circ} 04^{\prime} 04^{\prime \prime}$ \\
\hline & 22 & Aviação & $24^{\circ} 18^{\prime} 13^{\prime \prime}$ & $47^{\circ} 04^{\prime} 31^{\prime \prime}$ \\
\hline & 23 & Raposo Tavares & $24^{\circ} 17^{\prime} 55^{\prime \prime}$ & $47^{\circ} 08^{\prime} 06^{\prime \prime}$ \\
\hline & 24 & & $24^{\circ} 17^{\prime} 53^{\prime \prime}$ & $47^{\circ} 08^{\prime} 55^{\prime \prime}$ \\
\hline \multirow[t]{3}{*}{ Juquiá } & 25 & Estação & $24^{\circ} 19^{\prime} 33^{\prime \prime}$ & $47^{\circ} 37^{\prime} 53^{\prime \prime}$ \\
\hline & 26 & Parque Nacional & $24^{\circ} 18^{\prime} 56^{\prime \prime}$ & $47^{\circ} 38^{\prime} 03^{\prime \prime}$ \\
\hline & 27 & Vila Florida & $24^{\circ} 19^{\prime} 19^{\prime \prime}$ & $47^{\circ} 38^{\prime} 22^{\prime \prime}$ \\
\hline \multirow[t]{2}{*}{ Registro } & 28 & Vila São Francisco & $24^{\circ} 29^{\prime} 20^{\prime \prime}$ & $47^{\circ} 51^{\prime} 06^{\prime \prime}$ \\
\hline & 29 & Nosso Teto & $24^{\circ} 30^{\prime} 37^{\prime \prime}$ & $47^{\circ} 50^{\prime} 07^{\prime \prime}$ \\
\hline
\end{tabular}


Table 2. Number of snails collected on the north and south coast of São Paulo.

\begin{tabular}{cccc}
\hline \multirow{4}{*}{ North } & Municipality & B. tenagophila & B. straminea \\
\cline { 2 - 3 } & Caraguatatuba & 990 & 0 \\
& São Sebastião & 69 & 0 \\
& Ilhabela & 4 & 204 \\
& Ubatuba & 3 & 0 \\
& Itariri & 312 & 64 \\
& Juquiá & 221 & 0 \\
& Registro & 5 & 3 \\
& Total & 1604 & 271 \\
\hline
\end{tabular}

environmental surveillance for estimating risks and predicting the spread of schistosomiasis to new geographic regions.

\section{Material and Methods}

Snails were collected on the edges of water bodies and in the bottom of breeding sites in municipalities near the south coast of the state of São Paulo (Juquiá, Registro and Itariri) and on the north coast (São Sebastião, Caraguatatuba, Ubatuba and Ilhabela (Figure 1, Table 1). The municipality of Ilhabela is located on São Sebastião Island, which is $1.76 \mathrm{~km}$ from the mainland and the third largest island in Brazil (Cantarelli et al. 2014).

Collections were made between 2008 and 2013 and complied with Ministry of Health standards (Ministério da Saúde 2008) and the methodology standardized by the Superintendency for the Control of Endemics (SUCEN) for the Schistosomiasis Control Program in the State of São Paulo.

Once they had been collected, the snails were wrapped in dry gauze and sent to the laboratory for identification, which was based on the morphological characteristics of the genital system, as described in Paraense (1975, 1981). To ensure standard relaxation the snails were anesthetized with sodium pentobarbital (Deslandes 1959).

To analyze the relative frequency distribution of B. tenagophila specimens collected in four different locations (Travessão, Porto Novo, Morro do Algodão and Indaiá, in the municipality of Caraguatatuba); the chi-square test was used in a $4 \times 2$ table, as specified in Pereira (2001). The analysis took into account the different frequencies in October 2010 and June 2012. The Rio Claro site was not included in the analysis as there was no collection there in October 2010. Analysis of residuals (Zres) was carried out to determine which frequency was responsible for the significant result in the chi-square test. For a $5 \%$ significance level, residuals greater than 1.96 correspond to a greater number of occurrences than expected, and residuals less than -1.96 to a smaller number of occurrences than expected.

\section{Results and Discussion}

Of the 1875 planorbid snails from the genus Biomphalaria collected at the 29 collection points shown in Table $1,85.5 \%$ were identified as $B$. tenagophila and only $14.5 \%$ as $B$. straminea (Table 2). This finding confirms the predominance of B. tenagophila in the region, corroborating malacological surveys previously carried out in the same municipalities (Contino 2004, Teles et al. 2003, SUCEN 2005).

The snails were found in ditches, streams and flooded urban areas with aquatic plants and grasses on the edges.

B. tenagophila specimens collected in Morro de Algodão in Caraguatatuba form a distinct group from the other specimens because of the large absolute frequency of snails collected in the month of June. In this community, pathogens that cause severe diarrhea have historically affected a large section of the population (Asmus et al. 2013). The vulnerability of this area to floods, together with the high risk of disease transmission, makes constant malacological and environmental surveillance of Morro do Algodão essential.

In the comparison of relative frequencies of B. tenagophila for the four collection sites in the municipality of Caraguatatuba (Table 3), the chi-square test with three degrees of freedom showed that there was a statistically highly significant difference $\left(\mathrm{X}^{2}=61.425 ; \mathrm{p}<0.001\right)$ at the $5 \%$ level $(\mathrm{p}=0.05)$ between October 2010 and June 2012, indicating that the variation in the abundance of snails in the collection points is related to the collection period. The exception was Porto Novo, where the number of $B$. tenagophila specimens was expected to be higher in June. Analysis of residuals showed that the much smaller number than expected (Zres $=-29.347$ ) of B. tenagophila specimens in Porto Novo in June was probably responsible for the significant value observed in the chi-square test.

We believe that the low frequency of snails in Porto Novo may be related to treatment of the breeding site with insecticides or Baccilus thuringiensis, which are used in the area to control the Culex quinquefasciatus mosquito. It may also be related to mechanical control, including the cleaning and removal of waste from streams and their banks. Both types of control would prevent Culex breeding and indirectly increase the mortality rate of Biomphalaria.

The greatest number of snails was collected in June, when there is less rain and the smallest number in a period when rainfall increases. Our findings agree with previous filed studies that showed the impact of wet/dry seasons on planorbid populations (Barbosa \& Barbosa 1994, Camara et al. 2012, Fernandez et al. 2014).

Table 4 suggests that rainfall rather than temperature is a determining factor in the colonization of B. tenagophila. In months with little rainfall, such as June, freshwater habitats remain lentic for longer, allowing the snail population to grow and reproduce. In contrast, during periods of high rainfall and floods, when water levels rise and rivers burst their banks (all of which are common events on the north and south coast, according Pezzoli et al. 2013), growth of the Biomphalaria population is inhibited. It is probably during these months that the snail population disperses to new environments.

Table 3. Distribution of number of B. tenagophila specimens surveyed among the four sites at Caraguatatuba.

\begin{tabular}{lccccrr}
\hline Year/month & Travessão & Porto Novo & Morro do Algodão & Indaiá & Total & \% \\
\hline $10 / 10$ & 7 & 11 & 18 & 26 & 62 \\
$06 / 12$ & 160 & 14 & 297 & 389 & 919 \\
\hline
\end{tabular}


Table 4. Mean temperature $\left({ }^{\circ} \mathrm{C}\right)$ and rainfall $(\mathrm{mm})$ in the municipality of Caraguatatuba. (Source: CEPAGRI. Center for Meteorological and Climatic Research Applied to Agriculture. UNICAMP).

\begin{tabular}{lcccr}
\hline & \multicolumn{2}{c}{ Mean air temperature $\left({ }^{\circ} \mathbf{C}\right)$} & \multicolumn{2}{c}{ Rainfall $(\mathbf{m m})$} \\
\hline Month & Minimum & Maximum & Mean & \\
June & 14.3 & 27.9 & 21.1 & 64.3 \\
October & 18.4 & 31.9 & 25.2 & 160.0 \\
\hline
\end{tabular}

In this study we identified 204 specimens of B. straminea in the Barra Velha stream in Ilhabela (Figure 2), where previous malacological surveys had identified B. tenagophila and $B$. straminea living in sympatry (Teles et al. 2003). Our results corroborate the finding that $B$. straminea has a high potential for invading and rapidly colonizing new habitats, as described in studies carried out in Asia (Yipp 1990, Atwood et al. 2014) and on islands in the Caribbean (Pointier 1993). In some cases the competitive ability of $B$. straminea was sufficient to completely replace native species (Barboza et al. 2012, Barbosa et al. 2014). Based on the habitats in which the species in Ilhabela were collected, however, it is reasonable to suppose that $B$. straminea has a preference for freshwater bodies with abundant floating vegetation and that $B$. tenagophila prefers water collection with little vegetation like the drainage culvert in which the few specimens of this species collected in this study were found.

Notable in the southern region of the São Paulo coast was the finding of $B$. straminea in the Ana Dias district in the municipality of Itariri (Figure 2), where Muniz (2007) found only B. tenagophila. In 1980, Santos et al. reported finding $B$. straminea naturally infected with $S$. mansoni in the São Paulo municipality of Cruzeiro, in the valley of the Paraíba do Sul river. Dias et al. (1987) subsequently found that this population was susceptible to human and wild lineages of this trematode.

Global climate changes are expected to lead to higher rainfall, increasing water volumes in all Brazilian basins, including the Paraná river basin in the southeast of Brazil (Souza 2010, Valverde \& Marengo 2014). As a result, Biomphalaria species may be able to cross the natural limits to their geographic distribution and expand to new areas, increasing the risk of transmission of schistosomiasis (Coma et al. 2008, Githeko et al. 2010).

Our findings indicate that $B$. tenagophila is currently the predominant species of Biomphalaria on the São Paulo coastal fluvial plain. However, specimens of $B$. straminea were found in regions where $B$. tenagophila had previously predominated. This shows that there is a risk of the distribution patterns of $S$. mansoni intermediate host species changing as a result of the potential expansion of $B$. straminea into habitats naturally colonized by $B$. tenagophila. Such a change could represent an additional risk of infection for the human population, as $B$. straminea has been shown to be an important vector in areas where schistosomiasis is endemic, such as the northeast of Brazil.

\section{Acknowlegments}

We grateful acknowledge National Council for the Improvement of Higher Education (CAPES) for scholarship grant to Raquel Gardini Sanches Palasio, FAPESP for its financial support to Roseli Tuan (Grant Number 07/03458-7), and SUCEN for also supported this study. We are also thankful to Marisa Cristina de Almeida Guimarães and Kleber José Whitaker, who helped us with field surveys.

\section{References}

ASMUS, G.F., MELLO, A.Y.I., SEIXAS, S.R.C \& BATISTELLA, M. 2013. Análise sociodemográfica da distribuição espacial de ocorrências de diarréias agudas em áreas de risco de inundação. Caraguatatuba, SP. Revista Vitas: visões transdisciplinares sobre ambiente e sociedade 3 (6): 1-26.

ATTWOOD, S.W., HUO, G.N. \& QIU, J.W. 2014. Update on the distribution and phylogenetics of Biomphalaria (Gastropoda: Planorbidae) populations in Guangdong Province, China. Acta Trop. 1(14):S0001-706X.

BARBOSA, F.S., PEREIRA, C.D.P. \& ARRUDA, F. 1985. Competive interactions between species of freshwater snails .I. Laboratory studies: IC. Comparative survival of Biomphalaria glabrata and B.straminea kept out of water. Mem. Inst. Oswaldo Cruz 80(2): 155-157.

BARBOSA, C.S., BARBOSA, V.S., NASCIMENTO, W,C., PIERI, O.S. \& ARAUJO, K.C.G.M. 2014. Study of the snail intermediate hosts for Schistosoma mansoni on Itamaracá island on northeast Brazil: spacial displacement of Biomphalaria glabrata by Biomphalaria straminea. Geospatial Health 8(2): 345-351.

BARBOSA, F.S. \& BARBOSA, C.S. 1994.The bioecology of snail vectors for Schitosomiasis in Brazil. Cad. Saúde Pública (10)2: 200-209.

BARBOZA, D.M., ZHANG, C., SANTOS, N.C., SILVA, M.M., ROLLEMBERG, C.V., AMORIM, F.J., UETA, M.T., MELO, C.M., ALMEIDA, J.A., JERALDO, V. L. \& JESUS, A. R. 2012. Biomphalaria species distribution and its effect on human Schistosoma mansoni infection in an irrigated area used for rice cultivation in northeast Brazil. Geospatial Health 6(3): S103-S109.

BORELLI, E. 2008. Urbanização e qualidade ambiental: o processo de produção do espaço da costa brasileira. INTERthesis 4(1): 1-27.

CAMARA, I.A., BONY, Y.K., DIOMANDÉ, D., EDIA, O.E., KONAN, F.K., KOUASSI, C.N., GOURÈNE, G. \& POINTIER, J.P. 2012. Freshwater snail distribution related to environmental factors in Banco Natiomal Park an urban reserve in the Ivory Coast (West Africa). African Zoology 47(1): 160-168.

CANTARELI, C.V., DUTRA, M. \& TURAN, J. 2014. Aves ameaçadas da trilha e do entorno da comunidade da Praia do Bonete Ilhabela - SP. BioScience 3(3): 148-153.

CARNAVAL, A.C., MORITZ, C., HICKERSON, M., HADDAD, C. \& RODRIGUES, M. 2009. Stability predicts diversity in the Brazilian Atlantic Forest hotspot. Science 323: 785-789.

CEPAGRI. http://www.cpa.unicamp.br/outras-informacoes/clima_muni_ 269.html (last access: 16/03/2015).

COMA, M.S., VALERO, M.A \& BARGUES, M.D. 2008. Effects of climate change on animal and zoonotic helminthiasis. Rev Sci Tech. 27: 443-457.

CONTINO, M.L. 2004. Foco de esquistossomose - Litoral Norte do estado de São Paulo - Novembro 2003.

DE KOCK, K.N., WOLMARANS, C.T. \& BORMAN, M. 2004. Distribution and Habitats of B. pfeifferi snail intermediate host of S. mansoni in South Africa. Water SA. 30: 80-87.

DESLANDES,N. 1959. Técnica de dissecção e exame de planorbídeos. Rev Serv Espec Saúde Publica, 4(2): 371-382. 
DIEGUES, A.C., ARRUDA, R.S.V., SILVA, V.C.F., FIGOLS, F.A.B. \& ANDRADE, D. 2001. Os Saberes tradicionais e biodiversidade no Brasil. Ministério do Meio Ambiente, Brasília. 211 p.

DIAS, L.C.S., UETA, M.T \& GUARALDO, A.M.A. 1987. Suscetibilidade de Biomphalaria glabrata, B. straminea e B. tenagophila a diferentes cepas de Schistosoma mansoni. Revista do Instituto de Medicina Tropical de São Paulo 29(4): 205-212.

ESCOBAR, J.S., AULD, J.R., CORREA, A.C., ALONSO, J.M., BONY, Y.K., COUTELLEC, M.A., KOENE, J.M., POITIER, J. P., JARNE, P. \& VID, P. 2011. Patterns of mating system evolution in hermaphroditic animals: correlations among selfing rate, inbreeding depression, and the timing of reproduction. Evolution 65(5): 1233-1253.

FERNANDEZ, M.A., MATTOS, A.C., SILVA, E.F., SANTOS, S.B. \& THIENGO, S.C. 2014. A malacological survey in the Manso Power Plant, State of Mato Grosso, Brazil: new records of freshwater snails, including transmitters of schistosomiasis and exotic species. Rev. Soc. Bras. Med. Trop. 47( 4 ): 498-506.

GITHEKO, A., LINDSAY, S., CONFALONIERI, U. \& PATZ, J. 2010.Climate change and vector borne diseases: a regional analysis. Bull. World Health Organization 78: 1136-1147.

HEINO, J., MYKRÃ \& MUOTKA, T. 2009. Temporal variability of nestedness and idiosyncratic species in stream insect assemblages. Diversity and Distribuitions 15:198-206.

MCCREESH, N. \& BOOTH, M. 2014. The Effect of Increasing Water Temperatures on Schistosoma mansoni transmission and Biomphalaria pfeifferi population dynamics: An Agent Based Modelling Study. PLoS ONE 9(8): e105917.

MINISTÉRIO DA SAÚDE. 2008. Secretaria de Vigilância em Saúde. Departamento de Vigilância Epidemiológica. Vigilância e Controle de moluscos de importância epidemiológica: diretrizes técnicas: Programa de Vigilância e Controle da Esquistossomose (PCE). 2 ed. Editora MS, Brasília, DF, p. 43-49.

MUNIZ, C. 2007. Levantamento da malacofauna limnica e aspectos ecológicos de focos de esquistossomose em Ana Dias, Vale do Ribeira, SP. Dissertação de Mestrado, Universidade de São Paulo, São Paulo.

NOOTEN, S.S., ANDREW, N.R. \& HUGHES, L. 2014. Potential Impacts of Climate Change on Insect Communities: A Transplant Experiment. PLoS ONE 9(1): e85987.

PALASIO, R.G.S. 2013. Polimorfismo dos genes mitocondrial 16S rRNA e nuclear ITS2 em populações de Biomphalaria tenagophila da Bacia Litorânea do estado de São Paulo e estudo da suscetibilidade dos caramujos ao Schistosoma mansoni. Dissertação de Mestrado, Universidade Estadual de Campinas, Campinas, São Paulo.

PARAENSE, W.L. 1975. Estado atual da sistemática dos planorbídeos brasileiros. Arq. Mus. Nac. 55: 105-128.

PARAENSE, W.L. 1981. Biomphalaria sp.n. from South America (Mollusca Basommatophora Pulmonata). Mem. Inst. Oswaldo Cruz 76(2): 199-211.

PARMESAN, C. 2006. Ecological and evolutionary responses to recent climate change. Ann. Rev. Ecol. Evol. Syst. 37: 637-669.

PEREIRA, J.C.R. 2001. Analise de dados qualitativos: Estratégias metodológicas para as ciências da Saúde, humanas e sociais. 3 ed. Editora da Universidade de São Paulo, São Paulo.

PEZZOLI A., ALFREDINI, P., ARASAKI, E., ROSSO, M. \&, SOUZA JR,W.C. 2013. Impacts of climate change on management policy of the harbors, land areas and wetlands in the Sao Paolo State Coastline (Brazil). Adv Res Meteorol Sci 1:1-101.

PIZA, J.T. \& RAMOS, A.S. 1972. Os focos de esquistossomose no estado de São Paulo. Arquivo de Higiene e Saúde Pública 25(86): 261-271.

POINTIER, J.P. 1993. The introduction of Melanoides tuberculata (Mollusca: Thiaridae) to the island of SaintLucia (West Indies) and its role in the decline of Biomphalaria glabrata, the snail intermediate host of Schistosoma mansoni. Acta Tropica 54: 13-18.

ROCKSTRÖM, J., STEFFEN, W., NOONE, K., PERSSON, Å., CHAPIN, F.S. \& LAMBIN, E.F. 2009. A safe operating space for humanity. Nature 461: 472-475.

ROSENZWEIG, C., KAROLY, D., VICARELLI, M., NEOFOTIS, P., WU, Q., CASASSA, G., MENZEL, A., ROOT, T. L., ESTRELLA, N., SEGUIN, B., TRYJANOWSKI, P. \& LIU, C. 2008. Attributing physical and biological impacts to anthropogenic climate change. Nature 453 : 353-357.

SANTOS, L., COSTA, I.B., FIGUEIREDO, C.C.S.B. \& ALTOMANI, M.A.G. 1980. Primeiro encontro de Biomphalaria straminea (Dunker, 1848) no município de Cruzeiro, Vale do Paraíba, Estado de São Paulo, naturalmente infectada por cercarias de Schistosoma mansoni. Revista do Instituto Adolpho Lutz 40: ;165-166.

SILVA, L.J. 1985. Crescimento urbano e doenças. A esquistossomose no Município de São Paulo (Brasil). Revista Saúde Pública 19(1): 1-7.

SOUZA, C.R.G. 2005. Suscetibilidade morfométrica de bacias de drenagem ao desenvolvimento de inundações em áreas costeiras. Revista Brasileira de Geomorfologia 6(1): 45-61.

SOUZA, C.R.G. 2010. Impactos das mudanças climáticas no litoral do estado de São Paulo (Sudeste do Brasil). In VI Seminário Latino Americano de Geografia Física e II Seminário Ibero Americano de Geografia Física. Universidade de Coimbra, Portugal. p.1-17

SOUZA, C.R.G. \& SOUZA, A.P. 2004. Geologia e geomorfologia da área da estação ecológica Jureia-Itatins. In Estação Ecológica Jureia-Itatins. Ambiente Físico, Flora e Fauna (O.A.V. Marques \& W. Duleba eds). Holos Editora, cap. 2, p.16-33.

SUCEN. Superintendência de Controle de Endemias. 2005. Fichas de Distribuição de Planorbídeos capturados, examinados e positivos para Schistosoma mansoni, segundo localidade, no período de 2001 á 2005. Relatório Técnico do Serviço Regional 03, Taubaté, São Paulo.

TELES, H.M.S. \& MARQUES C.C.A. 1989. Estivação de Biomphalaria tenagophila (Pulmonata, Planorbidae). Rev. Saúde Pública 23(1): 76-78.

TELES, H.M.S. 1989. Distribuição de Biomphalaria tenagophila e B. occidentalis no Estado de São Paulo (Brasil). Rev. Saúde Pública 23(3): 244-253.

TELES, H.M.S., MITSUYOSHI, H.R., OLIVEIRA, J.C.N., \& AVEIRO, J.A. 2003. Ocorrência de vetores da esquistossomose mansônica no litoral norte do estado de São Paulo, Brasil. Cad. Saúde Pública 19(6): 1887-1891.

TELES, H.M.S. 2005. Distribuição geográfica das espécies dos caramujos transmissores de Schistosoma mansoni no estado de São Paulo. Rev. Soc. Bras. Med. Trop. 38(5): 426-432, http://dx.doi.org/10.1590/S0037-86822005000500013

TUAN, R. \& SIMOES, L.C.G. 1989. Spermatogenesis and desiccation in Biomphalaria tenagophila (Orbigny, 1835) (Gastropoda, Planorbidae). Revista Brasileira de Genética 12 (4): 881-885.

VALVERDE, M.C. \& MARENGO, J.A. 2014. Extreme Rainfall Indices in the Hydrographic Basins of Brazil. Open Journal of Modern Hydrology 4(1): 10-26.

VAZ, J.F. 1989. Distribuição de Biomphalaria tenagophila (d'Orgigny,1935) (GastropodaPulmonata). Ciência e Cultura 41: 14-27.

VIADANA, A.G. \& CAVALCANTI, A.P.B. 2006. Teoria dos refúgios florestais aplicadas ao estado de São Paulo. Revista da Casa da Geografia de Sobral 8 (1): 61-80.

YIPP, M.W. 1990. Distribution of the Schistosome vector snail, Biomphalaria straminea (Pulmonata: Planorbidae) in Hong Kong. J. Mollus. Stud. 56 (1): 47-55. 